\title{
Dietary effects of different organic acids on growth and nutrient digestibility of broiler
}

\author{
Ndelekwute $\mathrm{EK}^{1 *}{ }^{*}$, GE Enyenihi ${ }^{1}$, UL Unah ${ }^{1}$, HC Madu ${ }^{2}$ \\ ${ }^{1}$ Department of Animal Science, University of Uyo, Uyo, Nigeria; ${ }^{2}$ Department of Fisheries and Marine \\ Technology, Imo State Polytechnic, Umuagwo, Imo State, Nigeria
}

\begin{abstract}
An experiment was conducted to determine the effect of organic acids (acetic, butyric, citric and formic acids) on growth and nutrient digestibility of broilers. One hundred fifty (150) day old Hubbard chicks were used. There were five dietary treatments such viz Diet 1 as control contained no organic acid, diets $2,3,4$, and 5 contained $0.25 \%$ acetic, butyric, citric and formic acids, respectively. Each treatment was replicated three times having 10 birds arranged in completely randomized design (CRD). Feed and water were given ad libitum. Feeding of organic acid diets lasted for 7 weeks starting from the second week. At the starter phase, formic acid improved live weight. Feed and water intakes were significantly $(P<0.05)$ reduced by butyric acid. Feed: gain ratio was improved by formic acid. At the finisher phase, live weight was significantly $(P<0.05)$ improved by the acids except butyric acid. Feed intake, daily gain and feed: gain ratio were not significant $(P>0.05)$. Crude protein and ether extracts digestibility were improved by all the organic acids $(P<0.05)$. It is therefore concluded that $0.25 \%$ formic acid could be added to broiler diets.
\end{abstract}

Key words: broilers, growth, nutrient digestibility, organic acids Bangladesh Animal Husbandry Association. All rights reserved.

Bang. J. Anim. Sci. 2016. 45 (2): 10-17

\section{Introduction}

Recent concerns about antibiotics resistance in livestock industry indicate the need for alternative strategies to improve animal performance and health without the use of antibiotics. To this end some dietary products have been used to replace antibiotics in poultry diets. The products include; probiotics like yeast culture, prebiotic, essential oils, spices and organic acids (Cave, 1978; Chudhury, 2002; Patterson and Burkholder, 2003; Lesson et al., 2005; Windisch et al., 2008; Gao et al., 2008). Organic acids have been used for decades in feed preservation, protecting feed from bacterial and fungal destruction (Canibe et al., 2008). Evidence of the potentials of organic acids to support growth of broilers abounds (Waldroup et al., 1995; Ndelekwute et al., 2015). Growth promoting effect of organic acids is due to their antibacterial and antifungal effect and stimulation of villi growth (Lesson et al., 2005). In Nigeria and other developing countries, poultry production is improving and the demand for its meat and eggs is ever increasing.

*Corresponding author: ndelekwute.ek@gmail.com
Increasing demand for poultry meat has been attributed in part to meat consumers' desire to eat meat with lesser level of cholesterol in preference to red meat such as beef which contains higher cholesterol than poultry meat (Ndelekwute et al., 2008). With the increasing demand not only in Nigeria, but world over, animal nutritionists are faced with the task of producing feeds that could give heavier broiler chickens in good time. To this end, certain nutritional strategies have been adopted to achieve this, such as addition of feed additives to the feed to promote growth of monogastric animals (Partenen and Mroz, 1999). Such feed additives also regarded as growth promoters or enhancers are antibiotics (Dibner, 2004) and hormones (Maynard et al., 1981). Treatment feeds and feedstuffs against microbial entity is necessary because it had been reported that feeds and feedstuffs were contaminated by bacteria and fungi (Gathumbi et al., 1996).

Organic acids comprise of any organic carboxylic acid with the general formula $\mathrm{R}-\mathrm{COOH}$ such as acetic acid, butyric acid, citric acid, propionic acid, lactic acid and formic acid butyric, citric and formic acids) to improve growth and nutrient 
digestibility of broilers (Dibner,2004). The objective of this study was to evaluate the efficacy of four organic acids (acetic, (acetic, butyric, citric and formic acids) to improve growth and nutrient digestibility of broilers.

\section{Materials and Methods}

\section{Site of the experiment}

The experiment was conducted at the Teaching and Research Farm of the Department of Nutrition and Forage Science of the Michael Okpara University of Agriculture Umudike, Abia State, Nigeria. The average relative humidity during the experiment was over $72 \%$ and average ambient temperature of $28^{\circ} \mathrm{C}$.

Table 1.Ingredients and nutrients composition of starter diets

\section{Experimental design}

Completely randomized design (CRD) was followed for the experiment. One hundred fifty (150) day old chicks of Hubbard strains were used. These were divided into five treatments and replicated three times. Each replicate had 10 birds. T1 received no organic acid in the diet, $\mathrm{T} 2$ = acetic acid, T3 = butyric acid, T4 = citric acid, and $\mathrm{T} 5=$ formic acid. Each organic acid was added at $0.25 \%$ of the diets (Tables 1 and 2 ). The birds were stabilized in the brooding room for one week during which the control diet was feed to all the birds. At the end of the first week, the birds were allotted to the five treatment groups and fed organic acid diets for three weeks for starter phase and four weeks for the finisher phase.

\begin{tabular}{lccccc}
\hline Ingredients (\%) & Control & Acetic acid & Butyric acid & Citric acid & Formic acid \\
\hline Maize & 55.0 & 55.0 & 55.0 & 55.0 & 55.0 \\
Soybean mael & 28.0 & 28.0 & 28.0 & 28.0 & 28.0 \\
Fish meal & 3.00 & 3.00 & 3.00 & 3.00 & 3.00 \\
Palm kernel cake & 10.3 & 10.05 & 10.05 & 10.05 & 10.05 \\
Bone meal & 3.0 & 3.0 & 3.0 & 3.0 & 3.0 \\
Organic acid & - & 0.25 & 0.25 & 0.25 & 0.25 \\
Salt $\{$ NaCl) & 0.25 & 0.25 & 0.25 & 0.25 & 0.25 \\
Lysine & 0.10 & 0.10 & 0.10 & 0.10 & 0.10 \\
Methionine & 0.10 & 0.10 & 0.10 & 0.10 & 0.10 \\
${ }^{*}$ Premix & 0.25 & 0.25 & 0.25 & 0.25 & 0.25 \\
Total & 100 & 100 & 100 & 100 & 100 \\
Calculated nutrients (\%) & & & & & \\
Crude protein & 21.41 & 21.40 & 21.40 & 21.40 & 21.40 \\
Energy (MJME/kg) & 11.85 & 11.84 & 11.84 & 11.84 & 11.84 \\
Ether extract & 3.62 & 3.62 & 3.62 & 3.62 & 3.62 \\
Crude fibre & 4.38 & 4.36 & 4.36 & 4.36 & 4.36 \\
Ash & 6.54 & 6.54 & 6.54 & 6.54 & 6.54 \\
Calcium & 1.11 & 1.11 & 1.11 & 1.11 & 1.11 \\
Phosphorous & 0.86 & 0.84 & 0.84 & 0.84 & 0.84 \\
Lysine & 1.12 & 1.11 & 1.11 & 1.11 & 1.11 \\
Methionine & 0.55 & 0.54 & 0.54 & 0.54 & 0.54 \\
\hline
\end{tabular}

* premix supplied per kg starter diet: vitamin A 15,000 I.U, vitamin $D_{3} 13000$ iu, thiamin 2mg, Riboflavin 6mg, pyridoxine 4mg, Niancin $40 \mathrm{mg}$, cobalamine $0.05 \mathrm{~g}$, Biotin $0.08 \mathrm{mg}$, chooline chloride $0.05 \mathrm{~g}$, Manganese $0.096 \mathrm{~g}$, Zinc $0.06 \mathrm{~g}$, Iron $0.024 \mathrm{~g}$, Copper $0.006 \mathrm{~g}$, lodine $0.014 \mathrm{~g}$, Selenium $0.24 \mathrm{mg}$, Cobalt $0.024 \mathrm{mg}$ and Antioxidant $0.125 \mathrm{~g}$.

\section{Management of birds}

The birds were kept for one week in the brooding room. Heat was supplied by kerosene stove placed under a hover. At the end of the one week stabilization period the birds were transferred to a deep litter rearing house having wood shavings as bedding materials. A portion of the house where the birds were placed was covered with water proof material. They were randomly separated into the five treatment groups and weighed. Brooding continued to the third week of 
age. Feeding of acidified diets started at the second week. The birds were vaccinated against Newcastle disease and infectious bursal Table: 2. Ingredients and nutrients composition of finisher diets
(Gumboro) disease. Feed and water were supplied ad libitum.

\begin{tabular}{llllll}
\hline Ingredients (\%) & Control & Acetic acid & Butyric acid & Citric acid & Formic acid \\
\hline Maize & 55.00 & 55.00 & 55.00 & 55.00 & 55.00 \\
Soya bean meal & 25.00 & 25.00 & 25.00 & 25.00 & 25.00 \\
Fish meal & 2.00 & 2.00 & 2.00 & 2.00 & 2.00 \\
Palm kernel cake & 14.30 & 14.05 & 14.05 & 14.05 & 14.05 \\
Bone meal & 3.00 & 3.00 & 3.00 & 3.00 & 3.00 \\
Organic acid & - & 0.25 & 0.25 & 0.25 & 0.25 \\
Salt (NaCl) & 0.25 & 0.25 & 0.25 & 0.25 & 0.25 \\
Lysine & 0.10 & 0.10 & 0.10 & 0.10 & 0.10 \\
Methionine & 0.10 & 0.10 & 0.10 & 0.10 & 0.10 \\
*Premix & 0.25 & 0.25 & 0.25 & 0.25 & 0.25 \\
Total & 100 & 100 & 100 & 100 & 100 \\
Calculated (\%) & & & & & 19.84 \\
Crude protein & 19.85 & 19.84 & 19.84 & 19.84 & 12.00 \\
Energy (MJME/kg) & 12.05 & 12.00 & 12.00 & 12.00 & 5.42 \\
Ether extract & 5.40 & 5.42 & 5.42 & 5.42 & 5.58 \\
Crude fibre & 5.60 & 5.58 & 5.58 & 5.58 & 6.31 \\
Ash & 6.30 & 6.31 & 6.31 & 6.31 & 1.10 \\
Calcium & 1.09 & 1.10 & 1.10 & 1.10 & 0.72 \\
Phosphorous & 0.80 & 0.72 & 0.72 & 0.72 & 1.00 \\
Lysine & 1.02 & 1.00 & 1.00 & 1.00 & 0.44 \\
Methionine & 0.45 & 0.44 & 0.44 & 0.44 & \\
\hline
\end{tabular}

*premix supplied per kg finisher diet: vitamin 10, 0001.u., vitamin $D_{3}$ 12,0001.u. Vitamin E 201.U., Vitamin K2.5mg, thiamine 2.0mg, Riboflavin $3.0 \mathrm{mg}$, pyridoxine $4.0 \mathrm{mg}$, Niacin $20 \mathrm{mg}$, cobalamin $0.05 \mathrm{mg}$, pantthemic acid $5.0 \mathrm{mg}$, Folic acid $0.5 \mathrm{mg}$, Biotin $0.08 \mathrm{mg}$, choline chloride $0.2 \mathrm{mg}$, Manganese $0.006 \mathrm{~g}$, Zinc $0.03 \mathrm{~g}$, Copper $0.006 \mathrm{~g}$, lodine $0.0014 \mathrm{~g}$, Selenium $0.24 \mathrm{~g}$, cobalt $0.25 \mathrm{~g}$ and antioxidant $0.125 \mathrm{~g}$

\section{Data collection and digestibility trial}

Data were collected on feed intake, water intake and body weight. Feed intake and live body weight were used to calculate the feed: gain ratio. The total collection method was used to conduct the digestibility trial in metabolism cages. The metabolism room and cages were thoroughly washed and disinfected. At the end of the feeding experiment, one bird from each of the three replicates of a dietary group giving a total of 15 birds were randomly assigned to a metabolism cage. The weight of each bird used was similar to forestall the effect of weight on digestibility. The birds were acclimatized with ad libitum feeding for four days before fecal collection was carried out. At the end of the acclimatization period, a known quantity of feed was given daily to each bird. To minimize feed wastages, feeding was done in the morning by $8.00 \mathrm{hrs}$; in the afternoon by $1.00 \mathrm{hrs}$ and in the evening by $6.00 \mathrm{hrs}$ making sure the birds did not lack feed at any point in time. Each morning before feeding commenced, leftover feed was recorded and feed intake noted.

Feces were collected and weighed for five days. Collected feces were immediately taken to the laboratory where they were oven dried at $60^{\circ} \mathrm{C}$ to a constant weight. Dry fecal samples were ground to pass through $1 \mathrm{~mm}$ sieve. The five days fecal collection was pooled and thoroughly mixed together. A portion was taken, stored in a refrigerator from which proximate analysis was carried out according to AOAC (1990). Results of the proximate analysis were used to calculate the apparent nutrient digestibility was calculated as thus; Nutrient digestibility $(\%)=$

Nutrient in feed - nutrient in feces $\quad$ X 100 Nutrient in feed 


\section{Statistical analysis}

At the end of the experiment, data collected were subjected to analysis of variance (ANOVA). Significant means were separated using Duncan New Multiple Range Text (DNMRT) according to (Steel and Torrie, 1980).

\section{Results}

\section{Growth Performance}

Table 3 shows the effect of organic acids on performance of starter broilers. Initial body weight (weight after one week of stabilization in the brooding room) was not significant $(P>0.05)$ During the starter phase, organic acid treated diets significantly $(P<0.05)$ influenced the live weight. Formic acid diet produced the heaviest live weight compared to other diets except citric acid diet. Butyric acid treated diet produced the least live weight. Formic acid diet posted significantly $(P<0.05)$ better daily gain than the control and butyric acid, but similar to those of

Table 3. Effects of organic acids on starter broiler chicks citric and acetic acids. Butyric acid group significantly $(P<0.05)$ posted the least daily gain.

Daily feed intake was significantly better in birds fed the control diet and other organic acids compared to butyric acid. Birds that consumed formic acid diet significantly $(P<0.05)$ produced the best feed: gain ratio. Broilers on other organic acids produced feed: gain ratios that were similar $(P>0.05)$ to the control. Protein intake was significantly influenced $(P<0.05)$. Protein intake of butyric acid fed-birds was significantly less than those on citric and formic acids but similar $(P>0.05)$ to those on control and acetic acid diets. The result of the effect of organic acids on water intake indicated that the impact was significant $(P<0.05)$. Birds fed citric acid diet consumed more water than any other group followed by formic acid. There was no significant difference between the water intake of acetic acid group and that of the control. Butyric acid reduced $(P<0.05)$ water intake.

\begin{tabular}{lllllll}
\hline Ingredients (\%) & Control & Acetic acid & Butyric acid & Citric acid & Formic acid & SEM \\
\hline Parameters & & & & & & \\
Initial live weight $(\mathrm{g})$ & 72.00 & 76.00 & 77.00 & 74.00 & 74.67 & 1.11 \\
Final live weight $(\mathrm{g})$ & $560.00^{\mathrm{b}}$ & $580.00^{\mathrm{b}}$ & $500.00^{\mathrm{c}}$ & $598.33^{\mathrm{ab}}$ & $637.00^{\mathrm{a}}$ & 12.11 \\
Daily weight gain $(\mathrm{g})$ & $23.23^{\mathrm{b}}$ & $24.00^{\mathrm{ab}}$ & $20.14^{\mathrm{c}}$ & $24.97^{\mathrm{ab}}$ & $26.78^{\mathrm{a}}$ & 2.11 \\
Daily feed intake (g) & $53.90^{\mathrm{a}}$ & $55.25^{\mathrm{a}}$ & $48.70^{\mathrm{b}}$ & $58.49^{\mathrm{a}}$ & $56.11^{\mathrm{a}}$ & 3.53 \\
Feed: gain ratio & $2.32^{\mathrm{a}}$ & $2.30^{\mathrm{a}}$ & $2.42^{\mathrm{a}}$ & $2.34^{\mathrm{a}}$ & $2.10^{\mathrm{b}}$ & 0.01 \\
Daily protein intake (g) & $11.54^{\mathrm{ab}}$ & $11.83^{\mathrm{ab}}$ & $10.43^{\mathrm{b}}$ & $12.52^{\mathrm{a}}$ & $12.01^{\mathrm{a}}$ & 1.22 \\
Protein efficiency ratio & $2.01^{\mathrm{b}}$ & $2.03^{\mathrm{b}}$ & $1.93^{\mathrm{b}}$ & $1.99^{\mathrm{b}}$ & $2.23^{\mathrm{a}}$ & 0.10 \\
Daily water intake (ml) & $71.97^{\mathrm{b}}$ & $75.60^{\mathrm{b}}$ & $65.27^{\mathrm{c}}$ & $85.87^{\mathrm{a}}$ & $80.54^{\mathrm{a}}$ & 4.77 \\
Water: feed ratio & $1.34^{\mathrm{c}}$ & $1.37^{\mathrm{b}}$ & $1.34^{\mathrm{c}}$ & $1.47^{\mathrm{a}}$ & $1.44^{\mathrm{ab}}$ & 0.09 \\
\hline
\end{tabular}

*Superscripts $a, b, c, d$ mean along the same row with different superscripts are significantly $(p<0.05)$ different. SEM, Standard error means.

Table 4 shows the growth performance of broiler finisher chickens as affected by diets. Response of the birds to diets with organic acids was significantly different $(P<0.05)$ in some of the parameters measured except daily gain, feed: gain ratio, protein intake and protein efficiency ratio were similar $(P>0.05)$. All the birds on organic acid diets except butyric acid posted better final live weight compared to control. The final live weight of formic acid dietary group was similar to those of citric and acetic acids. The result also indicated clearly that citric and acetic acid dietary groups showed improvement over the control in terms of final live weight judging from the result of the starter phase. There was no significant difference in the same parameter at the starter phase between acetic acid, citric acid and the control. However, at the end of the finisher phase both acetic and citric acids were significantly $(P<0.05)$ superior. Weight gain of broilers fed butyric acid diets was improved over the control diet. This is because judging from the result of the starter phase, weight gain of butyric acid was significantly inferior to that of the control, but was no longer inferior at the finisher phase. 
Ndelekwute et al. (2016) Bang. J. Anim. Sci. 45 (2): 10-17

Table 4. Effects of organic acids on finisher broiler chicken

\begin{tabular}{lllllll}
\hline Organic acids & Control & Acetic acid & Butyric acid & Citric acid & Formic acid & SEM \\
\hline Parameters & & & & & & \\
Initial live weight $(\mathrm{g})$ & $560.00^{\mathrm{b}}$ & $580.00^{\mathrm{b}}$ & $500.00^{\mathrm{c}}$ & $598.33^{\mathrm{ab}}$ & $637.00^{\mathrm{a}}$ & 12.11 \\
Final live weight $(\mathrm{g})$ & $1705.3^{\mathrm{b}}$ & $1775.00^{\mathrm{a}}$ & $1589.67^{\mathrm{c}}$ & $1789.00^{\mathrm{a}}$ & $1831.33^{\mathrm{a}}$ & 27.80 \\
Daily weight gain $(\mathrm{g})$ & 40.90 & 42.68 & 38.92 & 42.81 & 42.83 & 3.45 \\
Daily feed intake $(\mathrm{g})$ & $109.15^{\mathrm{ab}}$ & $115.17^{\mathrm{ab}}$ & $106.17^{\mathrm{b}}$ & $118.62^{\mathrm{a}}$ & $116.71^{\mathrm{a}}$ & 10.26 \\
Feed: gain ratio & 2.67 & 2.70 & 2.73 & 2.77 & 2.72 & 0.15 \\
Daily protein intake $(\mathrm{g})$ & 21.67 & 22.86 & 21.07 & 23.55 & 23.17 & 1.66 \\
Protein efficiency ratio & 1.89 & 1.87 & 1.85 & $1 . .82$ & 1.85 & 0.08 \\
Daily water intake $(\mathrm{ml})$ & $163.90^{\mathrm{b}}$ & $192.88^{\mathrm{ab}}$ & $168.86^{\mathrm{b}}$ & $200.36^{\mathrm{a}}$ & $208.19^{\mathrm{a}}$ & 13.74 \\
Water: feed ratio & $1.50^{\mathrm{b}}$ & $1.67^{\mathrm{a}}$ & $1.59^{\mathrm{b}}$ & $1.69^{\mathrm{a}}$ & $1.78^{\mathrm{a}}$ & 0.06 \\
\hline
\end{tabular}

*Superscripts $a, b, c, d$ mean along the same row with different superscripts are significantly $(p<0.05)$ different. SEM, Standard error means.

Daily gain was the same $(P>0.05)$. However, formic, citric and acetic acid groups marginally showed some level of superiority over the control and butyric acid. Citric and formic acid diets significantly $(\mathrm{P}<0.05)$ produced higher daily feed intake than butyric acid diet. Daily feed intake of the control was similar to all the organic acids. It was observed that feed consumption of broilers fed butyric acid diet was improved at this phase. Citric and formic acid diets significantly $(P<0.05)$ improved daily water consumption over control and butyric acid diets. However, daily water intake for acetic acid was similar to control, butyric, citric and formic acids. The quantity of water consumed pet gram of feed (water: feed ratio) was higher in birds fed formic, citric and acetic acid diets compared to control and butyric acid diets. It was the same in control and butyric acid.

\section{Nutrient digestibility}

Table 5 shows the apparent nutrient digestibility of broilers as affected by diets. Nutrient digestibility were significantly $(P<0.05)$ influenced. Except for the dry matter, organic acids significantly improved digestibility of all the nutrients considered. In comparison to the control, protein was better digested by citric and formic acids; fibre by butyric and formic acids; ether extract by all the acids; ash by butyric, citric, and formic acids. Digestibility of nitrogen free extract was better in citric and formic acids. Energy utilization was significantly higher in all the organic acid groups.

\section{Discussion}

The improved growth of birds fed acetic acid, citric acid, formic acid, over those on control diet could be attributable to reported inhibitory and lethal effect of organic acids on pathogenic microflora and their contributions to digestion and absorption of nutrients in the gut. Many authors have reported antimicrobial actions of organic acids (Alshawabkeh et al., 2002; Sun, 2004; Paul et al., 2007), their ability to reduce the gut $\mathrm{pH}$ (Dibner, 2004) and inducement of endogeneous secretions such as bile and pancreatic enzymes (Thaela, 1998). These are key indicators for adequate nutrient digestion and utilization. Early feeding of organic acids in bird's life improves protein digestion, reduces colonization of the gut by E. coli, Salmonella, and Campylobacter which could cause thickening of the intestinal wall, reduction of villi height, number of villi, increase in crypt depth and promotion of fermentation in the foregut which hampers nutrient utilization (Debevere, 1987; Waldroup et al., 1995; Dibner, 2004; Canibe et al., 2008; Windisch et al., 2008). Therefore, any strategy which could increase the amount of acid in the proventriculus would improve protein digestion as the results on digestibility had shown. Improvement of growth performance of acetic, butyric and citric acids over the control at the finisher phase showed crossover (carryover) effect of the organic acids. It implies that feeding of such organic acids for a long period could improve their performance. 
Table 5. Effects of organic acids on nutrient digestibility of broiler chicken

\begin{tabular}{lllllll}
\hline Parameters (\%) & Control & Acetic acid & Butyric acid & Citric acid & Formic acid & SEM \\
\hline Dry matter & 66.44 & 64.46 & 68.56 & 68.34 & 68.34 & 1.01 \\
Crude protein & $62.87^{\mathrm{c}}$ & $63.21^{\mathrm{c}}$ & $66.04^{\mathrm{bc}}$ & $68.96^{\mathrm{ab}}$ & $70.98^{\mathrm{a}}$ & 3.21 \\
Crude fibre & $31.82^{\mathrm{b}}$ & $36.60^{\mathrm{ab}}$ & $39.33^{\mathrm{a}}$ & $37.14^{\mathrm{ab}}$ & $39.84^{\mathrm{a}}$ & 2.12 \\
Ether extract & $60.76^{\mathrm{b}}$ & $72.12^{\mathrm{a}}$ & $75.92^{\mathrm{a}}$ & $75.96^{\mathrm{a}}$ & $77.98^{\mathrm{a}}$ & 5.41 \\
Crude ash & $54.81^{\mathrm{b}}$ & $54.82^{\mathrm{b}}$ & $59.80^{\mathrm{a}}$ & $59.32^{\mathrm{a}}$ & $59.85^{\mathrm{a}}$ & 2.8 \\
Nitrogen free extract & $65.00^{\mathrm{b}}$ & $66.46^{\mathrm{b}}$ & $66.61^{\mathrm{b}}$ & $71.56^{\mathrm{a}}$ & $69.99^{\mathrm{a}}$ & 2.32 \\
Energy utilization & $62.00^{\mathrm{b}}$ & $68.86^{\mathrm{a}}$ & $67.40^{\mathrm{a}}$ & $69.10^{\mathrm{a}}$ & $68.25^{\mathrm{a}}$ & 3.9 \\
\hline
\end{tabular}

*Superscripts a, b, c, d mean along the same row with different superscripts are significantly $(p<0.05)$ different. SEM, Standard error means.

Hence prolonged feeding of organic acids could be advocated. Reduced feed intake induced by butyric acid could be due to its foul odour (the butyric acid treated feed smelled like liquid of fermented cassava). This could have been repulsive to adversely affect feed intake and consequently other performance indices. It has been stated that the required daily feed intake of birds must be met before optimum growth could be achieved (Oluyemi and Roberts, 2000). Feed intake below daily requirement could lead to shortfall in the daily requirement of nutrients and such birds perform poorly (Obioha, 1995)).

The feed and gain ratio of butyric acid that was similar to the control and other organic acids except formic acid, is an indication that its live weight may not be due to metabolic or physiological impairment but due to reduced feed intake. The ability of formic acid-fed birds to gain more weight per unit protein consumed, further shows the superiority of the acid as a growth promoter. Also better protein efficiency ratio of butyric acid compare to control, acetic and citric acids further explains that it may not have impaired the metabolic processes to produce the least body weight, but rather its daily feed intake may not have supplied the required quantity of nutrients for growth. This work corroborates earlier report (Skinner et al., 1991). In contrast, Paul et al. (2007) did not observe significant improvement. The disagreement of Paul et al. (2007) could be due to the fact that they conducted their experiment in cages. Organic acids are more effective in more contaminated environment as in deep litter house (Paul et al.,
2007) under which this experiment was conducted.

The relationship between water and feed intake was in consonant with the fact that quantity of water taken by birds has a direct relationship with the feed intake (Oluyemi and Roberts, 2000). This was clearly observed in water: feed ratio where citric and formic acids which consumed higher quantity of feed had the highest water: feed ratios.

\section{Apparent nutrient digestibility}

The current observations on digestibility of protein and ether extract could be attributed to earlier report (Dibner, 2004) that organic acids induced endogenous secretions such as protease and bile which are essential for nutrient utilization. The ability of the organic acids to reduce bacteria population in the gut has been reported (Canibe et al., 2008) and could have led to the better nutrient digestibility. In this regard, production of gases (such as ammonia, amines through fermentation caused by gram negative pathogenic bacteria), gut colonization and thickening of the intestinal wall which would have reduced digestibility and absorption of nutrients could have been inhibited (McHan, 1992; Thaela, 1998)). This result could be linked to the better performance in live weight observed of birds fed organic acid diets (except butyric acid). This result is in agreement with Kemme (1998) except in dry matter where he reported improved dry matter digestibility contrary to what was obtained in the present study. However, Hernandez et al. (2006) did not observe any significant differences 


\section{Conclusion}

Addition of organic acids especially formic acid in diets for broilers showed improvement in live weight at both the starter and finisher phases. Digestibility of nutrients was also improved. Therefore, addition of formic acid to broiler diets could be recommended.

\section{Acknowledgement}

The authors are grateful to the University of Uyo, Nigeria and the Tertiary Education Trust Fund (TETFUND), Nigeria for sponsoring this research. We are also grateful to Nekel Livestock Consultants, a Division of Nekel Agriculture Services, Uli, Anambra State, Nigeria for their technical support.

\section{References}

Alshawabkeh K, Tabbaa J (2002). Using dietary propionic acid to limit Salmonella gallinarum colonization in broiler chicks. Asian-Australian Journal of Animal Science 15(2): 243 - 246.

Association of Analytical Chemists (1990). Official Methods of Analysis. $14^{\text {th }}$ edition. Washington D.C., USA.

Canibe N, Emberg RM, Jensen BB (2008). An overview of the effect of organic acids on gut flora and gut health. Asian Journal of Poultry Science, 53: 75 - 78.

Cave NAG (1978). The influence of non - sterified fatty acids on feeding activity of chicks. Poultry Science, 57: 1124 - 1128.

Chudhury SR (2002). Effect of dietary garlic on cholesterol metabolism in laying hens. Poultry Science, 81, 1856 - 1862.

Debevere JM (1987). The use of buffered acidulant systems to improve the microbiological stability of acid foods. Journal of Food Microbiology, 4: 105 - 113.

Dibner J (2004). Organic acids: Can they replace antibiotic growth promoters. Feed Internation, 25(12): $14-16$.

Gao J, Zhang HJ, Yu SH, Wu SG, Yoon I, Quigley J, Gao YP, Qi GH (2008). Effects of yeast culture in broiler diets on performance and immunomodulatory functions. Poultry Science, 87, 1377 1384.

Gathumbi PO, Bebora LC, Muchiri DJ,Ngatia TA (1996). Mycologicalexamination of poultry feeds used in Nairobi Kenya. Bulletin of Animal Health and Production in Africa, 44 (1): $19-22$.
Hernandez F, Madrid J, Garcia V, Orengo J, Megias MD (2006). Influence of two plant extracts on broilers performance, digestibility and digestive organ size. Poultry Science, 83:169 - 174.

Hinton M, Linton AH, Perry FG (1995). Control of Salmonella by acid disinfection of chicks' food. Veterinary Research, 116, 502.

Kemme C (1998). The relationship between graded doses of Lupro-Cid and the apparent total tract digestibility of total phosphorus and calcium in growing pig. ID - DLO Report. No. 98012, Geneva.

Leeson S, Namkung $\mathrm{H}$, Ankongiovanni $\mathrm{H}$, Lee EH (2005). Effect of butyric acid on the performance and carcass yield of broiler chickens. Poultry Science, 84: 1418 1422

Maynard IA, Looshi JK, Hintz HF, Warner RC (1981). Animal nutrition. $7^{\text {th }}$ ed.Tata MeGraw - Hill Pub. New Delhi, India, P 356-370

McHan F (1992). Effects of butyric and lactic acids on continued colonization of Salmonella typhimurium in chick ceca when added to chick diets. Poultry Science, 71 (sup. 1): 115.

Ndelekwute EK, Uzogbu HO, Abdu LS (2008). Growth response of broiler starter chicks fed blood meal as a replacement for synthetic lysine. Proc. $42^{\text {nd }}$ Annual conf.Agric. Soc. Nigeria. P. 353 - 357.

Ndelekwute EK, Afolabi KD, Uzegbu HO, Essien EB (2015). Effect of dietary formic acid as replacement of streptomycin on growth and nutrient digestibility in broilers. Bangladesh Journal of Animal Science, 44(1): 69-74.

Obioha FC (1992). A Guide to poultry production in the tropics. $1^{\text {st }}$ edn. Ecena Publishers, Enugu, Nigeria, p.88 - 95.

Oluyemi JA, Roberts FA (2000). Poultry production in warm wet climate. $2^{\text {nd }}$ edn Spectrum Books Ltd Ibadan, Nigeria. P. 210

Partenen KH, Mroz Z (1999). Organic acids for performance enhancement in pigs diet. Nutrition Research, (12): 117 - 128.

Patterson JA, Burkholder KM (2003). Application of prebiotics, and probiotics in poultry production. Poultry Science, 82 : $627-631$.

Paul SK, Samanta G, Halder G, Biswas P (2007). Effect of a combination of organic acid salts as antibiotic replacers on the performance and gut health of broiler 
chickens. Livestock Research for Rural Development, 19 (11): $60-65$.

Skinner JT, Izat AI, Waldroup PW (1991). Research notes: Fumaric acid enhances performance of broiler chickens. Poultry Science, 70: $1444-1447$

Steel GD, Torrie JH (1980). Principles and Procedures of Statistics. $2^{\text {nd }}$ ed. McGraw Hill Book Company Inc, New York. P. 204220.

Sun $X$ (2004). Broiler performance and intestinal alterations when fed drug free diets. M.Sc. Thesis, Virginia Polytechnic Institute and State University, Virginia, USA. P. 96.
Thaela MJ (1998). Effect of dietary supplementation with lactic acid on endogenous secretions. Journal of Animal Feed Science and Technology, 7: 181 183.

Waldroup A, Kaniawati S, Mauromoustakos A (1995). Performance characteristics and microbiological aspects of broilers feed diets supplemented with organic acids. Journal of Food Protecton, 58 (5): 482 489.

Windisch W, Schedle K, Plitzner C, Kroismayr A (2007). Use of phytogenic products as feed additives for swine and poultry. Journal of Animal Science, 86 (E. Suppl.): E $10-$ E14. 